Men, Masculinities and the Modern Career 



\section{Men, Masculinities and the Modern Career}

Contemporary and Historical Perspectives

Edited by

Kadri Aavik, Clarice Bland, Josephine Hoegaerts, and Janne Salminen

\section{DE GRUYTER \\ OLDENBOURG}


An electronic version of this book is freely available, thanks to the support of libraries working with Knowledge Unlatched. $\mathrm{KU}$ is a collaborative initiative designed to make high quality books Open Access. More information about the initiative and links to the Open Access version can be found at www.knowledgeunlatched.org

\section{IRI Knowledge Unlatched}

The Open Access book is available at www.degruyter.com

Funded by the European Research Council (CALLIOPE ERC StG 2017) and by the Helsinki University 'Future Fund'.

ISBN 978-3-11-064734-1

e-ISBN (PDF) 978-3-11-065187-4

e-ISBN (EPUB) 978-3-11-064786-0

https://doi.org/10.1515/9783110651874

\section{(cc) BY-NC-ND}

This work is licensed under a Creative Commons Attribution-NonCommercial-NoDerivatives 4.0 International License. For details go to http://creativecommons.org/licenses/by-nc-nd/4.0/.

\section{Library of Congress Control Number: 2020939275}

\section{Bibliographic information published by the Deutsche Nationalbibliothek}

The Deutsche Nationalbibliothek lists this publication in the Deutsche Nationalbibliografie; detailed bibliographic data are available on the Internet at http://dnb.dnb.de.

(C) 2020 Kadri Aavik, Clarice Bland, Josephine Hoegaerts, and Janne Salminen, published by Walter de Gruyter GmbH, Berlin/Boston.

The book is published with open access at www.degruyter.com.

Cover image: okeyphotos/E+/Getty Images

Typesetting: Integra Software Services Pvt. Ltd.

Printing and binding: CPI books $\mathrm{GmbH}$, Leck

www.degruyter.com 